\title{
STATUS GIZI DAN PERSEN LEMAK TUBUH BERHUBUNGAN DENGAN USIA MENARCHE ANAK SEKOLAH DASAR DI SD MUHAMMADIYAH GKB 1 GRESIK
}

\author{
Nutritional Status and Body Fat Percentage Correlate with Menarche's Age among Students at \\ Muhammadiyah GKB 1 Elementary School \\ Anisaul Makarimah', Lailatul Muniroh² \\ ${ }^{1}$ Program Studi S1 Ilmu Gizi, Fakultas Kesehatan Masyarakat Universitas Airlangga, Surabaya \\ ${ }^{2}$ Departemen Gizi Kesehatan, Fakultas Kesehatan Masyarakat, Universitas Airlangga, Surabaya \\ Email: anisaulmakarimah@ymail.com
}

\begin{abstract}
ABSTRAK
Menarche adalah menstruasi pertama yang menjadi indikator seorang remaja putri memasuki masa pubertas. Dewasa ini terjadi pergeseran usia menarche ke arah yang lebih muda. Gaya hidup sedentari diyakini memegang peranan terhadap pergeseran usia menarche. Tujuan penelitian ini menganalisis hubungan antara status gizi dan persen lemak tubuh dengan usia menarche. Penelitian ini menggunakan desain cross sectional. Besar sampel sebanyak 37 siswi yang sudah mengalami menstruasi dan dipilih dengan menggunakan simple random sampling. Pengumpulan data meliputi pengukuran antropometri untuk menilai status gizi, sedangkan persen lemak tubuh dengan menggunakan Bioelectrical Impedance Analysis (BIA). Analisis data yang digunakan dalam penelitian ini adalah uji korelasi Spearman. Hasil penelitian menunjukkan bahwa lebih dari separuh $(51,4 \%)$ responden tergolong status gizi normal dan memiliki persen lemak tubuh yang healthy (89,2\%). Hasil analisis data menunjukkan terdapat hubungan antara status gizi $(\mathrm{p}=0,029$, $\mathrm{r}=-0,360)$ dan persen lemak tubuh $(\mathrm{p}=0,048, \mathrm{r}=-0,328)$ dengan usia menarche siswi di SD Muhammadiyah GKB 1 Gresik. Kesimpulan penelitian ini adalah semakin berlebih status gizi (z-score) dan persen lemak tubuh semakin dini usia menarche. Menormalkan status gizi dan persen lemak tubuh, salah satunya dengan cara menjaga pola konsumsi dan meningkatkan aktifitas fisik, seperti bersepeda, berenang, dan lainnya.
\end{abstract}

Kata kunci: persen lemak tubuh, status gizi, usia menarche

\begin{abstract}
Menarche is the first menstruation which can be indicator of teenage girls enter the puberty phase. Nowadays the age of menarche are younger. Sendentary lifestyle had played role in the shift of menarche age. The purpose of this study was to analyze the relation between nutritional status and body fat percentage with menarche age. This research used cross sectional design with sample size of 37 female students who had experienced menstruation and selected using simple random sampling. Data were collected by anthropometric measurements to assess nutritional status, body fat percentage using Bioelectrical Impedance Analysis (BIA). Data were analyzed by Spearman correlation test. The results showed that more than half of respondents had normal nutritional status (51.4\%) and healthy body fat percentage. There was a correlation between nutritional status $(p=0.029, r=-0.360)$ and body fat percentage $(p=0.048, r=-0.328)$ with age of menarche among teenage girls at the Muhammadiyah GKB 1 Gresik Elementary School. The conclusion of this study was higher nutritional status (score of z-score) and fat percentage will decrease the age of menarche. Research suggestion is to normalize nutritional status and percent body fat. By maintaining consumption pattern and increase physical activity, such as cycling, swimming, and others.
\end{abstract}

Keywords: body fat percentage, nutritional status, menarche age

\section{PENDAHULUAN}

Masa remaja merupakan masa transisi dari masa anak-anak menjadi masa dewasa yang umumnya terjadi di usia 10 hingga 14 tahun. Dan pada tahapan tersebut mereka membutuhkan perlindungan dan perhatian (UNICEF, 2016). Pubertas umumnya dialami oleh remaja, bagi perempuan salah satunya ditandai dengan kejadian menstruasi pertama atau yang biasa disebut dengan menarche. Klasifikasi pubertas yang terjadi pada 
remaja dibedakan menjadi 2 yaitu pubertas dini atau disebut dengan pubetas prekoks; apabila menarche terjadi di bawah usia 8 tahun, dan pubertas terlambat atau disebut dengan pubertas tarda; apabila menarche terjadi di atas usia 18 tahun (Uche-Nwachi, et al., 2007).

Menarche adalah menstruasi pertama yang dialami oleh remaja putri sebagai tanda bahwa ia telah mencapai kematangan reproduksi dan sedang berada pada masa pubertas (Proverawati dan Misaroh, 2009). Dewasa ini terjadi pergeseran usia menarche ke arah yang lebih muda (Rasjidi, 2010). Pernyataan ini diperkuat oleh penelitian Amaliah, et al. (2012) menunjukkan bahwa ratarata usia menarche pada remaja usia 10-15 tahun sebanyak 13.550 orang ialah 12,4 tahun. Menurut Hardiningsih dan Kusharisupeni (2013) rata-rata usia menarche di SD dan SMP Islam Syafi'iyah ialah 11,2 tahun. Modernisasi dan instanisasi gaya hidup yang berkembang saat ini menyebabkan adanya perubahan pada pola hidup maupun pola makan diyakini memegang peranan terhadap pergeseran usia menarche ke arah yang lebih muda dari waktu ke waktu. Berdasarkan data Riskesdas Tahun 2013 menunjukkan bahwa prevalensi remaja gemuk usia 13-15 tahun sebesar $10,8 \%$, dimana $2,5 \%$ diantaranya tergolong obesitas (Kemenkes, 2013).

Pubertas dini memiliki beberapa implikasi terhadap kesehatan remaja putri, antara lain meningkatnya risiko kanker payudara, namun kejadian ini bermula dari usia menarche dini dibarengi dengan kejadian obesitas abdominal serta peningkatan beberapa hormon, seperti insulin, testosteron, insulin like growth factor 1 yang bertindak sebagai faktor pertumbuhan untuk proliferasi jaringan kelenjar mamae dan memicu karsinogenik kelenjar mamae. Implikasi kesehatan lainnya ialah penyakit jantung, resistensi insulin, obesitas sentral, dan lainnya (Karapanou dan Anastasios, 2010).

Ada beberapa faktor yang memengaruhi usia menarche, antara lain usia menarche ibu (genetik), aktifitas fisik, pola konsumsi, stimulasi eksternal, faktor ekonomi, status gizi, dan persen lemak tubuh. Status gizi memiliki pengaruh kuat terhadap usia menarche, keluhan selama menarche, maupun lama hari menarche (Paath dan Heryanti, 2005).
Gizi anak dapat memengaruhi kecepatan pubertas yang dialaminya, semakin berlebih status gizinya maka usia menarche juga akan terjadi lebih dini. Berbagai penelitian menunjukkan bahwa remaja yang mengalami menarche lebih dini memiliki berat badan yang lebih besar. Menurut Wiknjosatro (2005), status gizi gemuk memiliki keterkaitan yang erat dengan persen lemak tubuh tinggi. Berdasarkan penelitian Santrock (2007), persen lemak tubuh yang diperlukan oleh remaja putri untuk dapat memicu terjadinya menarche minimal $17 \%$. Variabel persen lemak tubuh dipilih karena variabel ini merupakan salah satu indikator pengukuran antropometri gizi serta dapat menggambarkan perbandingan massa lemak dengan massa bebas lemak pada tubuh seseorang (Gibson, 2005).

Database siswa SD Muhammadiyah GKBI Gresik menunjukkan bahwa mayoritas siswa berasal dari keluarga ekonomi menengah ke atas yang dibuktikan dengan mayoritas pekerjaan orang tua sebagai karyawan swasta, selain itu rata-rata pendapatan orang tua sebesar Rp 3.543.284, angka ini di atas UMK Gresik. Berdasarkan studi pendahuluan yang dilakukan pada bulan Maret 2017 kepada 49 siswi yang telah mengalami menstruasi menunjukkan rata-rata usia menarche di SD Muhammadiyah GKB 1 Gresik 10,3 tahun. Pernyataan ini mendukung penelitian Karapanou dan Anastasios (2010) bahwa remaja putri yang dibesarkan di lingkungan perkotaan memiliki usia menarche lebih awal. Oleh sebab itu peneliti tertarik untuk melakukan penelitian mengenai hubungan status gizi dan persen lemak tubuh dengan usia menarche.

\section{METODE}

Penelitian ini merupakan jenis penelitian kuantitatif yang bersifat observasional dengan desain cross sectional. Populasi pada penelitian ini ialah siswi kelas 5 dan 6 yang sudah mengalami menstruasi sejumlah 49 orang.

Berdasarkan perhitungan sampel, besar sampel pada penelitian ini sebesar 37 siswi. Pengambilan sampel dilakukan dengan menggunakan teknik simple random sampling dengan bantuan software komputer. 
Penelitian ini dilakukan pada bulan Maret hingga Juli 2017 di SD Muhammadiyah GKB 1 Gresik. Variabel terikat pada penelitian ini adalah usia menarche, sedangkan variabel bebas terdiri dari status gizi yang menggunakan indikator indeks massa tubuh menurut umur (IMT/U) dan persen lemak tubuh. Data primer pada penelitian ini terdiri atas pengukuran antropometri untuk menentukan status gizi responden berupa tinggi badan yang diukur menggunakan mikrotoa stature meter 2 meter dengan ketelitian $0,1 \mathrm{~cm}$ dan berat badan serta persen lemak tubuh yang diukur menggunakan alat Bioelectrical Impedance Analysis (BIA) merk Omron "Karada Scan Body Composition Monitor HBF-358-BW" dengan ketelitian \pm 400 gram untuk berat badan $0,0-40,0$ $\mathrm{kg}$, sedangkan untuk berat badan 40,0-135,0 kg memiliki ketelitian $\pm 1 \%$. Beberapa jenis BIA dapat digunakan untuk mengukur persen lemak tubuh pada remaja usia minimal 17 tahun, namun BIA yang digunakan pada penelitian ini dapat digunakan untuk usia 10 hingga 80 tahun. Data sekunder diambil melalui database yang diberikan oleh pihak sekolah berupa nama, usia, kelas saat ini, dan alamat responden.

Analisis statistik yang digunakan ialah korelasi Spearman dengan tingkat kemaknaan $\alpha<0,05$. Penelitian ini telah dikaji dan lulus uji laik etik dari Komisi Etik Penelitian Kesehatan Fakultas Kesehatan Masyarakat Universitas Airlangga dengan nomor sertifikat 333-KEPK.

\section{HASIL DAN PEMBAHASAN}

\section{Karakteristik Responden}

Berdasarkan Tabel 1, usia responden sebagian besar $(67,6 \%)$ berusia 12 tahun, pendidikan terakhir orang tua Perguruan Tinggi (PT), dan pekerjaan ayah sebagai pegawai, sedangkan hampir sebagian ibu tidak bekerja. Responden yang mengalami menarche di usia 11 tahun sebesar 43,2\% (Tabel 1). Rata-rata usia menarche responden 10 tahun 8 bulan.
Tabel 1. Distribusi Karakteristik Responden

\begin{tabular}{lcc}
\hline \multicolumn{1}{c}{ Karakteristik Responden } & n & $\mathbf{\%}$ \\
\hline Usia Responden (tahun) & & \\
10 tahun & 1 & 2,7 \\
11 tahun & 11 & 29,7 \\
$\quad 12$ tahun & 25 & 67,6 \\
Tingkat Kelas & & \\
$\quad$ Kelas 5 & 15 & 40,5 \\
$\quad$ Kelas 6 & 22 & 59,5 \\
Usia Menarche (tahun) & & \\
$\quad 10$ tahun & 13 & 35,1 \\
11 tahun & 16 & 43,2 \\
12 tahun & 8 & 21,7 \\
\hline
\end{tabular}

Tabel 2. Distribusi Karakteristik Orang Tua Responden

\begin{tabular}{lcccc}
\hline Karakteristik Orang & \multicolumn{2}{c}{ Ayah } & \multicolumn{2}{c}{ Ibu } \\
\cline { 2 - 5 } Tua Responden. & $\mathbf{n}$ & $\mathbf{\%}$ & $\mathbf{n}$ & $\mathbf{\%}$ \\
\hline Tingkat Pendidikan & & & & \\
SMP & 1 & 2,7 & 0 & 0 \\
SMA & 10 & 27 & 13 & 35,1 \\
Perguruan Tinggi & 26 & 70,3 & 24 & 64,9 \\
Jenis Pekerjaan & & & & \\
Tidak Bekerja & 0 & 0 & 16 & 43,3 \\
Wiraswasta & 12 & 32,4 & 5 & 13,5 \\
Petani/Buruh & 0 & 0 & 0 & 0 \\
Pegawai & 22 & 59,5 & 13 & 35,1 \\
Lainnya & 3 & 8,1 & 3 & 8,1 \\
Total & 37 & 100 & 37 & 100 \\
\hline
\end{tabular}

\section{Status Gizi dan Persen Lemak Tubuh}

Lebih dari separuh responden tergolong status gizi normal $(51,4 \%)$. Rata-rata nilai $z$-score IMT/U adalah 0,73 . Berdasarkan klasifikasi yang ada, nilai ini termasuk dalam kategori status gizi normal.

Sebesar $89,2 \%$ responden memiliki persen lemak tubuh yang healthy. Cut off point persen lemak tubuh yang digunakan untuk mengklasifikasikan kelebihan lemak tubuh ialah $\geq 30 \%$ (William dan Don, 2002). Rata-rata persen lemak tubuh responden $24,5 \%$, berdasarkan 


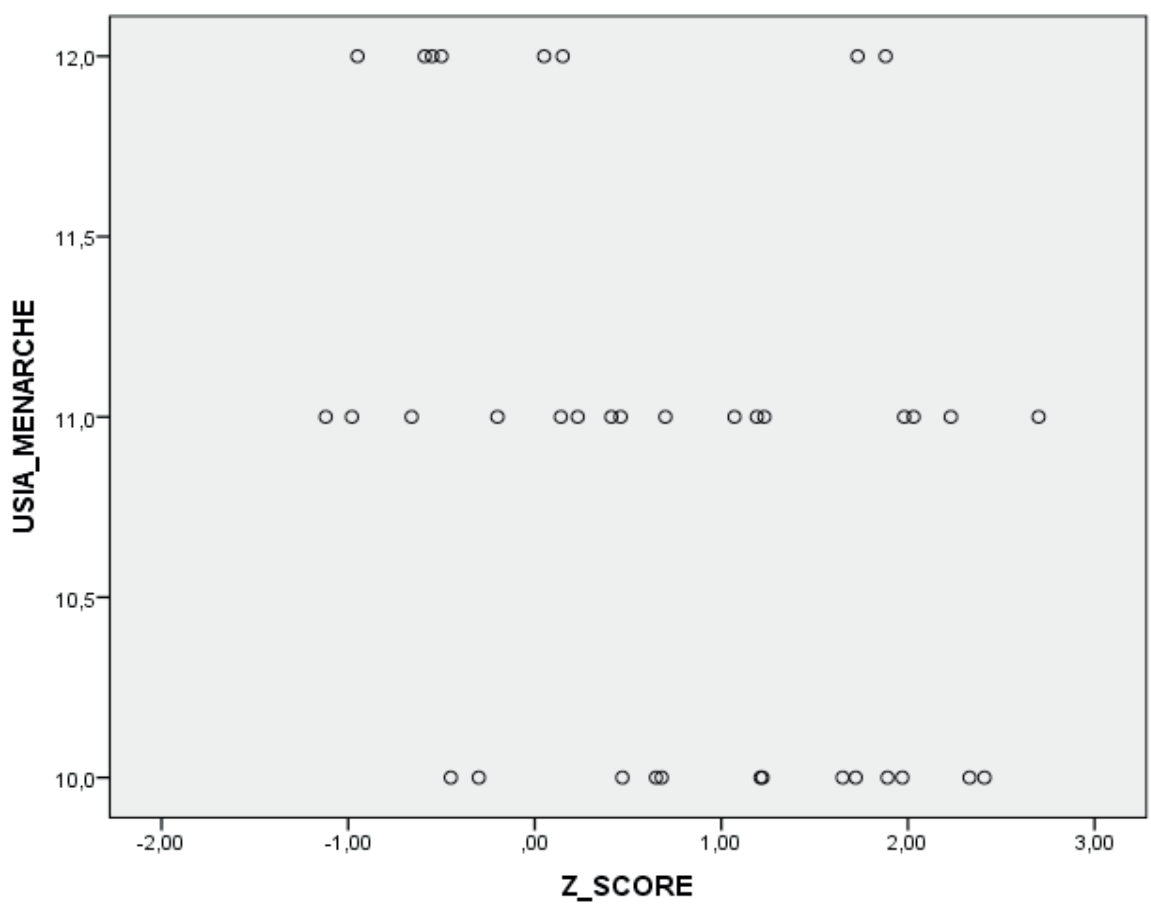

Gambar 1. Scatter Plot Hubungan antara Status Gizi dengan Usia Menarche Siswi

Tabel 3. Distribusi Responden berdasarkan Status Gizi dan Persen Lemak Tubuh

\begin{tabular}{lcc}
\hline \multicolumn{1}{c}{ Karakteristik Responden } & $\mathbf{n}$ & $\mathbf{\%}$ \\
\hline Status Gizi & & \\
Gemuk & 13 & 35,1 \\
Normal & 19 & 51,4 \\
Kurus & 0 & 0 \\
$\quad$ Sangat Kurus & 0 & 0 \\
Persen Lemak Tubuh & & \\
$\quad$ Underfat & 0 & 0 \\
Healthy & 33 & 89,2 \\
Overfat & 4 & 10,8 \\
$\quad$ Obese & 0 & 0 \\
Total & 37 & 100 \\
\hline
\end{tabular}

klasifikasi yang ada nilai ini termasuk dalam kategori persen lemak tubuh healthy.

\section{Hubungan antara Status Gizi dengan Usia Menarche}

Gambar 1 menunjukkan bahwa tren persebaran status gizi responden berada di antara nilai $z$-score $0,0-1,0$, yang mana nilai tersebut termasuk dalam kategori status gizi normal. Hampir sebagian mengalami menarche di usia 11 tahun. Analisis yang digunakan untuk mengetahui
Tabel 4. Hasil Uji Statistik Hubungan antara Status Gizi dan Persen Lemak Tubuh dengan Usia Menarche

\begin{tabular}{lcc}
\hline \multicolumn{1}{c}{ Variabel } & p & r \\
\hline Status gizi & 0,029 & $-0,360$ \\
Persen lemak tubuh & 0,048 & $-0,328$ \\
\hline
\end{tabular}

hubungan antara status gizi dengan usia menarche ialah korelasi Spearman. Analisis ini digunakan karena kedua variabel baik status gizi maupun usia menarche berskala data rasio namun usia menarche berdasarkan hasil uji normalitas menggunakan Shapiro Wilk menunjukkan bahwa data tidak berdistribusi normal.

Berdasarkan hasil analisis hubungan dengan korelasi Spearman yang disajikan pada Tabel 4 diperoleh nilai $p$ value yaitu 0,029 . Nilai $\mathrm{p}<0,05$ sehingga $\mathrm{H}_{0}$ ditolak yang berarti ada hubungan antara status gizi dengan usia menarche. Kuat hubungan antara kedua variabel ini dapat dilihat dari nilai koefisien korelasi Spearman sebesar $-0,360$ yang artinya ada hubungan namun lemah antara status gizi dengan usia menarche. Klasifikasi kuat lemahnya nilai koefisien korelasi Spearman mengacu pada Sugiyono (2012). 


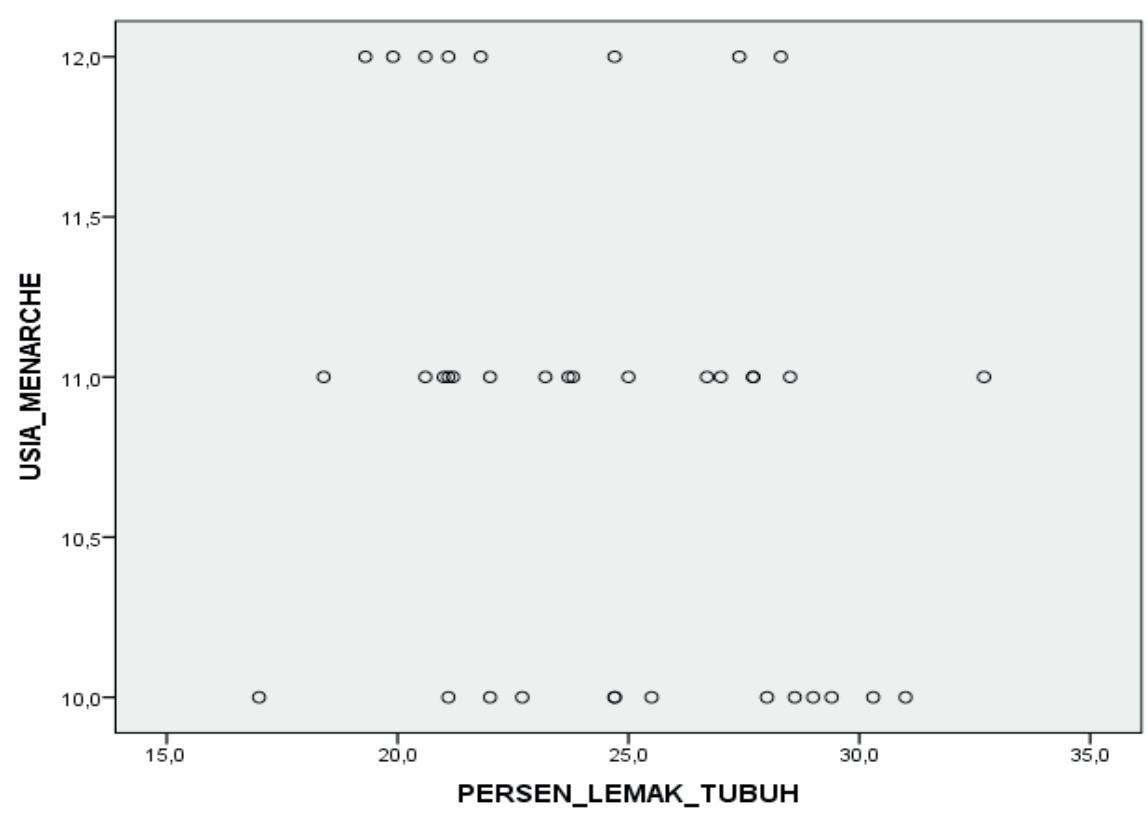

Gambar 2. Scatter Plot Hubungan antara Persen Lemak Tubuh dengan Usia Menarche Siswi

Berdasarkan penjelasan di atas dapat disimpulkan bahwa hasil penelitian ini sesuai dengan teori yang menyatakan adanya hubungan antara status gizi dengan usia menarche, semakin berlebih status gizi seseorang maka menarche akan terjadi di usia yang lebih dini. Status gizi seseorang dapat memengaruhi kematangan seksualnya sehingga remaja putri yang mengalami menarche lebih cepat cenderung memiliki status gizi lebih dibandingkan dengan remaja putri yang mengalami menarche normal dan terlambat (Waryana, 2010).

Status gizi umumnya dikaitkan dengan asupan makanan yang dikonsumsi, apabila asupan gizi melebihi kebutuhan harian dapat memengaruhi status gizi yang berdampak pada perkembangan organ reproduksi, begitupula sebaliknya apabila asupan gizi di bawah kebutuhan harian dapat menyebabkan penurunan fungsi reproduksi yang berdampak pada keterlambatan menstruasi. Pernyataan ini sesuai dengan penelitian Putri dan Soenarnatalina (2013) menunjukkan bahwa pola konsumsi lemak, protein hewani dan nabati, fast food, dan soft drink memiliki hubungan dengan usia menarche. Rendahnya aktifitas fisik yang salah satunya disebabkan pengaruh gaya hidup sedentari saat ini memicu kejadian menarche terjadi lebih dini. Pernyataan ini sesuai dengan penelitian Sofya
(2015) menunjukkan adanya hubungan signifikan antara aktifitas fisik dengan usia menarche pada remaja putri atlet dan non atlet.

Kedua faktor di atas memiliki pengaruh terhadap status gizi akan tetapi hal tersebut tidak bisa dijadikan sebagai patokan karena terdapat faktor-faktor lain yang juga dapat berpengaruh terhadap status gizi, seperti faktor lingkungan remaja putri itu sendiri seperti media massa, faktor genetik, dan lainnya. Penelitian terkait hubungan antara status gizi dengan usia menarche sudah banyak diteliti dan menunjukkan hasil bahwa terdapat hubungan antara status gizi dengan usia menarche. Penelitian Maulina (2015) menunjukkan bahwa terdapat hubungan antara status gizi dengan usia menarche pada remaja putri di SMP Negeri 21 Padang Tahun 2015, selain itu penelitian-penelitian lain yang mendukung hasil penelitian ini antara lain (Agustin, 2010; Prabasiwi, 2011; Laadjim, 2013; dan Wahyuni, 2013).

\section{Hubungan antara Persen Lemak Tubuh dengan Usia Menarche}

Gambar 2 menunjukkan tren persebaran persen lemak tubuh responden berada di antara $20-29 \%$, nilai tersebut termasuk dalam kategori persen lemak tubuh healthy. Hampir sebagian besar mengalami menarche diusia 11 tahun. 
Korelasi Spearman yang menunjukkan nilai $p=0,048$. Nilai $p<0,05$ yang artinya ada hubungan antara persen lemak tubuh dengan usia menarche. Kuat hubungan antara kedua variabel ini dapat dilihat dari nilai koefisien korelasi Spearman sebesar -0,328 yang memiliki arti bahwa kedua variabel ini memiliki hubungan namun kekuatan hubungan tersebut tergolong lemah. Berdasarkan penjelasan di atas dapat disimpulkan bahwa hasil penelitian ini sesuai dengan teori yang ada bahwa ada hubungan antara persen lemak tubuh dengan usia menarche, semakin tinggi persen lemak tubuh seseorang maka usia menarche akan semakin dini.

Menurut Acharya, et al. (2006) lemak tubuh memiliki hubungan erat dengan IMT karena nilai IMT yang tinggi dapat mengindikasi lemak tubuh yang lebih tinggi. Pernyataan ini didukung oleh penelitian yang telah dilakukan oleh Handayani, et al. (2013) menunjukkan bahwa terdapat hubungan signifikan antara status gizi berdasarkan IMT/U dengan persen lemak tubuh.

Jaringan lemak tubuh dalam memengaruhi permulaan pubertas dikaitkan dengan kadar leptin yang disekresi oleh kelenjar adiposa. Pernyataan ini selaras dengan penelitian Hendri, et al. (2009) menunjukkan bahwa terdapat hubungan yang bermakna dan korelasi positif kuat antara persentase lemak tubuh dengan kadar leptin serum. Keterkaitan antara persen lemak tubuh dengan usia menarche diperjelas oleh Uche-Nwachi, et al. (2007), tingginya persen lemak tubuh menyebabkan kadar leptin serum meningkat, peningkatan kadar leptin memicu peningkatan serum LH, dimana hormon ini berfungsi untuk sekresi hormon esterogen dan progesteron dalam ovarium sehingga semakin tinggi persen lemak tubuh seseorang maka jumlah hormon estrogen dan progesteron dalam ovarium juga semakin meningkat lebih dini dari yang seharusnya, kejadian ini yang mengakibatkan kematangan reproduksi terjadi lebih awal, salah satunya ditandai dengan menstruasi pertama. Hasil penelitian ini didukung oleh penelitian (Dahliansyah, 2007; Prabasiwi, 2011; Siswianti, 2012; dan Handayani, et al., 2013).

\section{KESIMPULAN DAN SARAN}

Status gizi dan persen lemak tubuh dengan usia menarche memiliki hubungan yang berbanding terbalik pada siswi di SD Muhammadiyah GKB 1. Semakin berlebih status gizi dan persen lemak tubuh yang tinggi maka semakin dini usia menarche.

Saran bagi sekolah yaitu membantu siswi untuk menormalkan status gizinya bagi siswi yang termasuk berstatus gizi gemuk maupun obesitas dengan cara mengaktifkan kembali senam bersama yang dilakukan seminggu sekali guna meminimalkan risiko kejadian menarche dini serta membantu siswi untuk menurunkan persen lemak tubuh bagi siswi yang termasuk memiliki persen lemak tubuh overfat supaya menekan risiko terjadinya menarche dini.

Saran bagi siswi antara lain membatasi konsumsi fast food, soft drink, dan makananmakanan lain yang mengandung tinggi lemak dan kalori serta meningkatkan aktifitas fisik agar status gizi siswi yang mengalami kegemukan maupun obesitas dapat kembali ke status gizi normal sehingga menarche dini tidak terjadi.

\section{DAFTAR PUSTAKA}

Acharya, A., Reddaiah, V.P., \& Baridalyne, N. (2006). Nutritional status and menarche in adolescent girls in an urban resettlement Colony of South Delhi. Indian Journal of Community Medicine, 31(4), 302-303. Diakses dari: http:// medind.nic.in/iaj/t06/i4/iajt06i4p302.pdf.

Agustin, I.D. (2010). Hubungan antara status gizi, aktifitas fisik, dan tingkat sosial ekonomi terhadap kejadian menarche remaja putri di SMP Negeri 17 Bekasi Tahun 2010 (Skripsi tidak dipublikasikan). Universitas Indonesia, Depok, Indonesia.

Amaliah, N., Kencana, S., \& Bunga Ch.R. (2012). Status tinggi badan pendek berisiko terhadap keterlambatan usia menarche pada perempuan remaja usia 10-15 tahun (Stunting Increased Risk of Delaying menarche on Female Adolescent Aged 10-15 Years). Jurnal Penel Gizi Makan, 35(02), 150-158. Diakses dari: http://ejournal.litbang.depkes.go.id/index.php/ pgm/article/view/3383/3376>. 
Dahliansyah. (2008). Hubungan indeks massa tubuh dengan persentase lemak tubuh dengan usia menarche dan keteraturan siklus menstruasi (studi pada siswi SMPN 1 Hulu Gurung Kabupaten Kapuas Hulu Kalimantan Barat Tahun 2007) (Skripsi, Universitas Diponegoro, Semarang). Diakses dari http://eprints.undip. ac.id/6949/1/3296.pdf.

Gibson, R.S. (2005). Principles of nutritional assessment (2nd ed). Modison Avenue: Oxford University Press.

Handayani, M.S., Cesilia, M. D., \& Hadi, R. (2013). Hubungan komposisi tubuh dan status gizi dengan perkembangan seksual pada remaja putri di perkotaan dan perdesaan. Jurnal Gizi dan Pangan, 8(3), 181-186. Diakses dari http:// journal.ipb.ac.id/index.php/jgizipangan/article/ view/7978/6260.

Hardiningsih, A. \& Kusharisupeni. (2013). Faktor-faktor yang berhubungan dengan status menarche pada siswi sekolah dasar (SD) dan sekolah menengah pertama (SMP) Islam As-Syafi'iyah Bekasi Tahun 2013 (Skripsi, Universitas Indonesia, Depok). Diakses dari http://lib.ui.ac.id/naskahringkas/2015-09/ S52620-Aulia\%20Hardiningsih.

Hendri, D., Putri S.L., Yusrawati, \& Hafni B. (2009). Hubungan kadar leptin serum, indeks massa tubuh, persentase lemak tubuh, dan rasio lingkar pinggang panggul dengan usia menarche (Tesis, Universitas Andalas, Padang). Diakses dari http://repository.unand. ac.id/18483/1/HUBUNGAN\%20KADAR\%20 LEPTIN\%20SERUM.pdf.

Karapanou, O. \& Anastasios, P. (2010). Determinants of menarche. BioMed Central, 8(1), 115. Diakses dari http://www.rbej.com/content/8/1/115.

Kementerian Kesehatan RI. (2013). Riset Kesehatan Dasar (Riskesdas) 2013. Jakarta: Badan Penelitian dan Pengembangan Kesehatan. Diakses dari http://www.depkes.go.id/resources/ download/general/Hasil\%20Riskesdas\%20 2013.pdf.

Laadjim, S. A. (2013). Hubungan status gizi dengan usia menarche pada remaja putri di SMPN 8 Kota Gorontalo Tahun 2013. Karya Ilmiah Mahasiswa (KIM) Fakultas Ilmu Kesehatan dan Keolahragaan, 1(01). Diakses dari: http:// kim.ung.ac.id/index.php/KIMFIKK/article/ view/2830/2806.

Maulina, A. (2015). Hubungan antara status gizi dan aktifitas fisik dengan usia menarche pada remaja putri di SMP Negeri 21 Padang (Skripsi, Universitas Andalas, Padang). Diakses dari http://repository.unand.ac.id/23084/1/ REPOSITORY.pdf.

Paath, R. \& Heryati. (2005). Komponen zat gizi. Jakarta: Dian Rakyat.

Prabasiwi, A. (2011). Hubungan antara status gizi dengan status menarche pada siswi SMP Negeri 10 Kota Tegal. Jurnal Senit, 106-111. Diakses dari http://download.portalgaruda.org/article.p hp? article $=447647 \& \mathrm{val}=9476 \&$ title $=$ Hubunga $\mathrm{n} \% 20$ Antara $\% 20$ Status $\% 20$ Gizi $\% 20$ Dengan $\% 20$ Status $\% 20$ menarche $\% 20$ Pada $\% 20$ Siswi $\% 20$ Smp\%20Negeri\%2010\%20Kota\%20Tegal.

Proverawati, A., \& Misaroh, S. (2009). Menarche menstruasi pertama penuh makna. Yogyakarta: Nuha Medika.

Putri, R.L.D. \& Soenarnatalina, M. (2013). Analisis faktor hubungan usia menarche dini. Jurnal Biokep, 2(1), 42-50. Diakses dari download.portalgaruda.org/article. php? article $=144419 \& \mathrm{val}=1099$.

Rasjidi, I. (2010). 100 questions \& answer “kanker pada wanita”. Jakarta: PT Elex Media Komputindo.

Santrock, J.W. (2007). Perkembangan anak edisi kesebelas jilid 1. (11st ed.). Jakarta: Erlangga.

Siswianti, Y.A. (2012). Hubungan berat badan, persen lemak tubuh, status gizi (IMT/U), umur menarche ibu dengan umur menarche pada siswi di SDN Cikaret 01 Cibinong Kabupaten Bogor Tahun 2012 (Skripsi, Universitas Indonesia, Depok). Diakses dari http://lib. ui.ac.id/file?file=digital/20318212-S-Yanti\%20 Afrian $\% 20$ Siswianti.pdf.

Sugiyono. (2012). Metode penelitian kuantitatif, kualitatif, dan R\&D. Cetakan ke 17. Bandung: Alfabeta.

Sofya, S.N.Y. (2015). Hubungan aktifitas fisik dengan usia menarche pada remaja putri atlet dan non atlet. (Skripsi, Institut Pertanian Bogor, Bogor). Diakses dari http://repository.ipb.ac.id/ handle/123456789/75547.

Uche-Nwachi, E.O., Odekunle, A., Gray, J., Bethel, T., Burrows, Y., Carter, J., Christie., K., Dillet, J., Evelyn, C., Stubbs, L., Osolo, I., \& Workman, T. (2007). Mean age of menarche in trinidad and its relationship to body mass index, ethinicity and mothers age of menarche. Online Journal of Biological Sciences, 7(2), 66-71. Diakses dari http://thescipub.com/PDF/ojbsci.2007.66.71. pdf. 
UNICEF. (2016). Adolescents and youth. Diakses dari https://www.unicef.org/adolescence/.

Wahyuni, S. (2013). Hubungan status gizi antropometri dan usia menarche pada siswi MTs N Tangerang II Pamulang Tahun 2013 (Skripsi, Universitas Islam Negeri Syarif Hidayatullah). Diakses dari http://repository.uinjkt.ac.id/ dspace/bitstream/123456789/26423/1/ SEPTIA\%20WAHYUNI-FKIK.pdf.
Waryana. (2010). Gizi reproduksi. Yogyakarta: Pustaka Rihama.

William, B. \& Don, W. F. (2002). Buku ajar histologi. (Edisi 12). Terjemahan Jan Tambayong. Jakarta: EGC.

Wiknjosastro, H., (2005). Ilmu kebidanan. (3rd ed.). Jakarta: Yayasan Bina Pustaka Sarwono Prawirohardjo. 